\title{
Steric influence of adamantane substitution in tris-urea receptor: encapsulation of sulphate and fluoride-water cluster
}

\author{
SANTANU KAYAL, UTSAB MANNA and GOPAL DAS*(1) \\ Department of Chemistry, Indian Institute of Technology Guwahati, Guwahati 781 039, Assam, India \\ E-mail: gdas@iitg.ernet.in
}

MS received 9 March 2018; revised 30 May 2018; accepted 31 May 2018; published online 9 July 2018

\begin{abstract}
Tris(2-aminoethyl)amine (tren)-based bulky adamantane group-substituted tris-urea (L) has been developed as the potential tripodal receptor exhibiting strong binding affinities towards small spherical fluoride anion as well as large tetrahedral sulphate anion in its neutral and protonated form, respectively. Structural elucidation reveals that the divalent sulphate ion is fully engulfed inside the complementary space created by two face-to-face oriented symmetry-independent protonated receptors, whereas the smaller fluoride ion is encapsulated as fluoride-water cluster $\left(\mathrm{F}^{-}-\mathrm{H}_{2} \mathrm{O}\right)$ assemblage within the neutral unimolecular capsular assembly of receptor $\mathbf{L}$.
\end{abstract}

Keywords. Anion recognition; sulphate anion; fluoride-water cluster; tris-Urea receptor; steric hindrance.

\section{Introduction}

In supramolecular chemistry, the encapsulation and recognition of anions within the self-assemblies of host molecules is an area of immense research interest due to the essential biological roles of anions ${ }^{1-6}$ and also because of their influence in clinical, environmental and industrial purposes. ${ }^{7}$ Understanding of hydrated-anions is a highly appreciated area of research due to their structures, energetics and activities in hydrated state. ${ }^{8}$ The behavior of anions in their hydrated form are curiously different from the naked anions as the surrounding hydration networks hugely affect their activity. As a result, ordered anion-water cluster allows researchers to explore the molecular interaction of anion-water with the synthetic receptors. ${ }^{9}$ Study in natural systems, e.g., chloride-binding protein dehalogenase, sulphatebinding protein of Salmonella typhimurium bacteria, phosphate-binding protein of Escherichia coli bacteria, etc., have shown that protein can efficiently and selectively bind anions by several non-covalent interactions and this observation have inspired the researchers to develop various receptors that employ hydrogen bonds accessed by specific binding sites from amide, ${ }^{10}$ urea/thiourea, ${ }^{11}$ pyrrole ${ }^{12}$ and indole ${ }^{13}$ functionalities for binding of anionic guests. Tripodal scaffolds provide a structurally flexible pre-organized space used in the field of anion-recognition and anion-induced formation of capsular assemblies. ${ }^{14}$ One of the most interesting features of molecular capsules is their ability to isolate encapsulated guest from the bulk medium and this is known as molecular sorting. ${ }^{15}$ To bind with anions/hydrated anions, one or more host molecules with favorable binding sites may be required in the host-guest system so that high salvation energy of anions must be compensated. Among oxyanions, sulphate recognition by synthetic receptors has attracted tremendous attention due to its essential role in permanent hardness of water, as a pollutant in nuclear and radioactive waste, interfering in the vitrification process. ${ }^{16}$ Subsequently, the extraction from aqueous phase to organic phase is very difficult due to very high standard Gibbs energy of hydration $\left(-1080 \mathrm{~kJ} \mathrm{~mol}^{-1}\right) .{ }^{17}$ Among the halides, excess presence of fluoride in drinking water causes dental and skeletal fluorosis besides its small size, high electronegativity, high hydration energy. The essential roles of the smallest halide anion (fluoride) in food, biology, industry and toxicity ${ }^{18-21}$ motivate the researchers to encapsulate the fluoride inside the synthetic receptor scaffolds. Continuing our group's

\footnotetext{
*For correspondence

Electronic supplementary material: The online version of this article (https://doi.org/10.1007/s12039-018-1504-6) contains supplementary material, which is available to authorized users.
} 
ongoing research interest in the field of supramolecular chemistry of anions and anion-water clusters, ${ }^{22-35}$ herein we structurally demonstrate $2: 1(\mathbf{L})_{2}-\mathbf{S O}_{4}^{2-}$ protonated dimeric host-guest capsular assembly (complex 1) and cation-sealed 1:1 L- $\left[\left(\mathrm{F}^{-}\right)\left(\mathrm{H}_{2} \mathrm{O}\right)\right]$ (complex 2) neutral capsular assembly of bulky adamantine-substituted $C_{3 v}$ symmetric tris-urea scaffold.

\section{Experimental}

\subsection{Materials and methods}

All the reagents and solvents were purchased from commercial sources and used without any purification. Tren [tris(2-aminoethyl)-amine],1-adamantylamine and tetrabutylammonium salts were purchased from Sigma-Aldrich while common inorganic acids were purchased from local vendors in India and used without further purification. Solvents used for synthesis and crystallization were purchased from Merck, India and used as supplied. ${ }^{1} \mathrm{H}$ NMR spectra were recorded on a Varian FT-400 MHz instrument and chemical shifts were recorded in parts per million (ppm) on a scale using tetramethylsilane $\left[\mathrm{Si}\left(\mathrm{CH}_{3}\right)_{4}\right]$ or a residual solvent peak as a reference. ${ }^{13} \mathrm{C}$ spectra were obtained at $100 \mathrm{MHz}$. The electrospray ionization mass spectrometry (ESI-MS) spectrum of $\mathrm{L}$ was recorded in methanol. The FT-IR spectra of airdried samples were recorded on a Perkin-Elmer-Spectrum on FT-IR spectrometer with $\mathrm{KBr}$ disks over the range of 4000 $450 \mathrm{~cm}^{-1}$.

\subsection{Synthesis and characterization}

2.2a Synthesis of receptor $\boldsymbol{L}$ : Tren-based tris-adamantyl tris-urea was synthesized in good yield as shown in Scheme 1. To a freshly dried THF (40 mL) 1-adamantyl isocyanate $(0.578 \mathrm{~g}, 0.003 \mathrm{~mol})$ was added and the solution was stirred under $\mathrm{N}_{2}$ atmosphere for $5 \mathrm{~min}$. Then tris-(2 aminoethyl) amine, tren $(0.158 \mathrm{~g}, 0.001 \mathrm{~mol})$ was further added dropwise and the reaction mixture was stirred at room temperature under $\mathrm{N}_{2}$ atmosphere. After $1 \mathrm{~h}$, a pale yellow precipitate appeared but reaction mixture was further allowed to stir for $12 \mathrm{~h}$. After $12 \mathrm{~h}$, the reaction was stopped, the pale yellow precipitate was filtered off and was washed several times with THF, methanol and diethyl ether to remove unreacted starting material and further dried in vacuum. M.p.: $160-162{ }^{\circ} \mathrm{C},{ }^{1} \mathrm{H}$ NMR (400 $\mathrm{MHz}$, DMSO-d $\left.\mathrm{d}_{6}\right) \delta(\mathrm{ppm}): 1.595\left(18 \mathrm{H}, \mathrm{CH}_{2}\right), 1.865(18 \mathrm{H}$, $\mathrm{CH}_{2}$ ), 1.979 (9H, -CH), 2.387-2.418 9 (t, $6 \mathrm{H}, \sim 12.4 \mathrm{~Hz}-$ $\mathrm{NCH}_{2} \mathrm{CH}_{2}$ ), 2.939-2.982 (q, 6H, $\left.11.6 \mathrm{~Hz},-\mathrm{NCH}_{2}\right), 5.564$ (s, $\left.3 \mathrm{H},-\mathrm{NH}_{\mathrm{b}}\right), 5.695-5.722\left(\mathrm{t}, 3 \mathrm{H}, \sim 10.8 \mathrm{~Hz},-\mathrm{NH}_{\mathrm{a}}\right) .{ }^{13} \mathrm{C} \mathrm{NMR}$ $\left(100 \mathrm{MHz}, \mathrm{DMSO}-\mathrm{d}_{6}\right) \delta(\mathrm{ppm}): 29.42(\times 9 \mathrm{C}), 36.59(\times 9 \mathrm{C})$, $37.75\left(\times 3 \mathrm{C},-\mathrm{NCH}_{2}\right), 42.50(\times 9 \mathrm{C}), 49.87(\times 3 \mathrm{C}), 54.95(\times 3 \mathrm{C}$, $\left.-\mathrm{NCH}_{2} \mathrm{CH}_{2}\right), 157.61\left(\times 3 \mathrm{C}\right.$, carbonyl-C). FT-IR $\left(\mathrm{v} \mathrm{cm}{ }^{-1}\right)$ : 3363 vs $(\mathrm{N}-\mathrm{H}), 2906$ vs $(\mathrm{C}-\mathrm{H}), 2854$ vs $(\mathrm{C}-\mathrm{H}), 1638$ vs $(\mathrm{C}=\mathrm{O})$, $1561 \mathrm{vs(HCH}$ of adamantyl). ESI-MS: m/z 678.5071 [L + H]

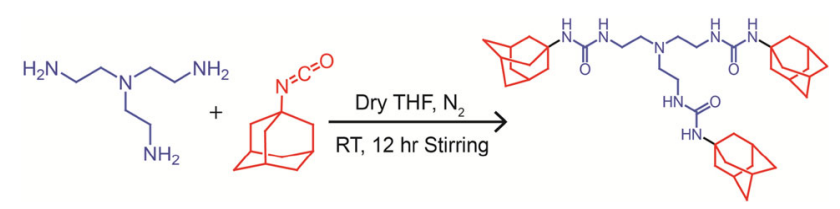

Scheme 1. Synthetic route and molecular structure of tris-urea receptor $\mathbf{L}$.

Table 1. Crystallographic parameters and refinement details of complexes.

\begin{tabular}{|c|c|c|}
\hline $\begin{array}{l}\text { Parameters } \\
\text { CCDC No. }\end{array}$ & $\begin{array}{c}\text { Complex } 1 \\
1820662\end{array}$ & $\begin{array}{c}\text { Complex } 2 \\
1820663\end{array}$ \\
\hline Formula & $\mathrm{C}_{78} \mathrm{H}_{125} \mathrm{~N}_{14} \mathrm{O}_{10} \mathrm{~S}$ & $\mathrm{C}_{55} \mathrm{H}_{99} \mathrm{FN}_{8} \mathrm{O}_{4}$ \\
\hline $\mathrm{Fw}$ & 1450.98 & 955.42 \\
\hline Crystal system & Trigonal & Monoclinic \\
\hline Space group & $R 3$ & $P 21 / c$ \\
\hline $\mathrm{a} / \AA$ & $40.470(2)$ & $16.773(10)$ \\
\hline $\mathrm{b} / \AA ̊$ & $40.470(2)$ & $14.270(10)$ \\
\hline $\mathrm{c} / \AA ̊$ & $13.853(12)$ & $26.288(17)$ \\
\hline$\alpha /{ }^{\circ}$ & 90.00 & 90.00 \\
\hline$\beta /{ }^{\circ}$ & 90.00 & $114.690(4)$ \\
\hline$\gamma /{ }^{\circ}$ & 120.00 & 90.00 \\
\hline $\mathrm{V} / \AA^{3}$ & $19649(3)$ & $5716.5(7)$ \\
\hline $\mathrm{Z}$ & 9 & 4 \\
\hline $\mathrm{D}_{\mathrm{c}} / \mathrm{g} \mathrm{cm}^{-3}$ & 1.104 & 1.110 \\
\hline$\mu \mathrm{Mo} \mathrm{K}_{\alpha} / \mathrm{mm}^{-1}$ & 0.096 & 0.072 \\
\hline $\mathrm{T} / \mathrm{K}$ & $298(2)$ & $298(2)$ \\
\hline$\theta \max$. & 24.998 & 25.000 \\
\hline Total no. of reflections & 33529 & 34270 \\
\hline Independent reflections & 13757 & 9777 \\
\hline Observed reflections & 5233 & 6872 \\
\hline Parameters refined & 977 & 617 \\
\hline $\mathrm{R}_{1}, \mathrm{I}>2 \sigma(\mathrm{I})$ & 0.1067 & 0.1007 \\
\hline $\mathrm{wR}_{2}$ (all data) & 0.2800 & 0.1957 \\
\hline $\operatorname{GOF}\left(F^{2}\right)$ & 1.047 & 1.126 \\
\hline
\end{tabular}

2.2b Synthesis of sulphate complex $\left[\left(\mathrm{LH}^{+}\right)_{2}\left(\mathrm{SO}_{4}^{2-}\right)\right]$ (1): Sulphate complex of protonated $\mathbf{L}$ was obtained as suitable crystal for X-ray diffraction analysis upon slow evaporation of a $2 \mathrm{~mL}$ DMF mixture of $\mathbf{L}$ and 2 drops of conc. $\mathrm{H}_{2} \mathrm{SO}_{4}$. The colorless crystals of sulphate complex through proton transfer of $\mathrm{H}_{2} \mathrm{SO}_{4}$ with ligand were attained after 15 days and separated by filtration.

2.2c Synthesis of fluoride-water complex [(n-TBA) $\left.\left\{(\mathrm{L})(\mathrm{F})\left(\mathrm{H}_{2} \mathrm{O}\right)\right\}\right](\mathbf{2})$ : Cation-sealed fluoride-water complex of neutral receptor, $\mathbf{L}$ was acquired as suitable single crystal for X-ray diffraction analysis by adding excess tetrabutylammonium fluoride to a $2 \mathrm{~mL}$ solution of DMF of $\mathbf{L}$ in a small glass vial. Then, resulting mixture was stirred for 10 min and kept in the open atmosphere at room temperature for slow evaporation. After 20 days, a colorless crystal of X-ray quality was obtained. 


\subsection{Crystallographic refinement details}

The crystallographic refinement details of data collection for anion complexes $\mathbf{1}$ and $\mathbf{2}$ are summarized in Table 1 and all the data have been deposited to the CCDC. In each case, a crystal of suitable size was selected from the mother liquor. Intensity data for all crystals were collected Mo $\mathrm{K} \alpha$ radiation $\left(\lambda=0.71073 \AA\right.$ ) at $298 \mathrm{~K}$, with increasing $\omega$ (width of $0.3^{\circ}$ per frame) at a scan speed of $6 \mathrm{~s} /$ frame on a Bruker SMART APEX diffractometer equipped with CCD area detector. The data integration and reduction were processed with SAINT software. ${ }^{36}$ An empirical absorption correction was applied to the collected reflections with SADABS. ${ }^{37}$ The structures were solved by direct methods using SHELXTL ${ }^{38}$ and were refined on F2 by the full-matrix least squares technique using the SHELXL-2014 program package. ${ }^{39}$ Graphics are generated using MERCURY $2.3{ }^{40}$ In all cases, non-hydrogen atoms are treated anisotropically.

Wherever possible, the hydrogen atoms are located on a difference Fourier map and refined. In other cases, the hydrogen atoms are geometrically fixed. It is important to mention that in the case of complexes $\mathbf{2}$, we could not add a hydrogen atom to water molecules even after many trials. The O-H bond of water molecule was very large and could not be refined. Crystallographic noncovalent interactions data are summarized in Table S1 (Supporting Information).

\section{Results and Discussion}

\subsection{Structure of sulphate complex $\left[\left(\mathrm{LH}^{+}\right)_{2}\left(\mathrm{SO}_{4}{ }^{2-}\right)\right]$}

The asymmetric unit of complex 1 comprises of two symmetry-independent protonated receptor units and one sulphate anion (consisting of eight half-occupied oxygen atoms). The X-ray analysis reveals that two protonated symmetry-independent ligand units orient in face-to-face fashion, effectively encapsulating a large tetrahedral sulphate anion inside the dimeric receptor cage assembly (Figure 1b) (capsular size $\mathrm{d}_{\mathrm{N} 1 \cdots \mathrm{N} 8}=$ $10.027 \AA$ in 1) by fifteen strong $\mathrm{N}-\mathrm{H}_{\text {receptor }} \cdots \mathrm{O}_{\text {sulphate }}$ and one $\mathrm{C}-\mathrm{H}_{\text {adamantane }} \cdots \mathrm{O}_{\text {sulphate }}$ hydrogen bonding interactions with receptor $\mathbf{L}$ (Figure $1 \mathrm{~b}$ ). The $\mathrm{X}$-ray analysis clearly shows that the O8B oxygen atom of sulphate ion accepts five $\mathrm{N}-\mathrm{H} \cdots \mathrm{O}$ hydrogen bonds (four with urea $-\mathrm{N}-\mathrm{H}$ group and one with apical $-\mathrm{N}-\mathrm{H}$ group of the receptor) (Figure 1b). On the other hand, O9B atom accepts three and $\mathrm{O} 10 \mathrm{~B}$ receives four strong $\mathrm{N}-\mathrm{H} \cdots \mathrm{O}$ hydrogen bonds from six urea $-\mathrm{N}-\mathrm{H}$ groups of the receptor (Figure 1b). Note that, the fourth oxygen atom O7B of sulphate is also tetra-coordinated like $\mathrm{O} 10 \mathrm{~B}$ atom, although $\mathrm{O} 7 \mathrm{~B}$ receives three strong $\mathrm{N}-\mathrm{H} \cdots \mathrm{O}$ and one $\mathrm{C}-\mathrm{H}_{\text {adamantane }} \cdots \mathrm{O}$ bonds from the receptor (Figure $1 \mathrm{~b}$ ). Hence, the divalent sulphate anion in dimeric complex $\mathbf{1}$ exhibits optimal coordination number that is consistent
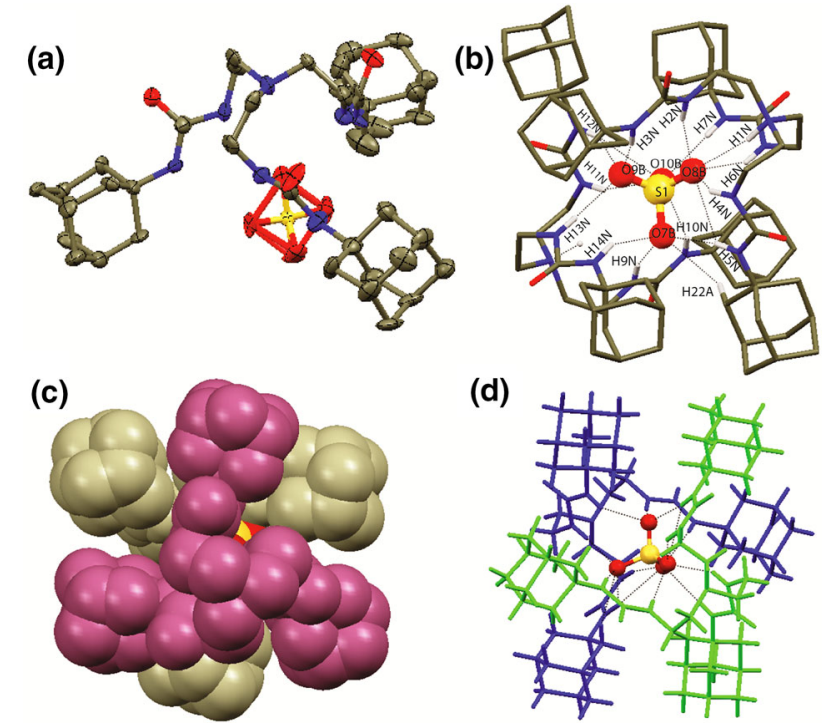

Figure 1. Partial $X$-ray structures of complex 1. (a) ORTEP diagram with $30 \%$ probability; (b) H-bonding contacts; (c) Entrapment of guest within the receptor dimer (Space fill representation); (d) symmetric equivalent units present in the dimeric cavity of the receptor.

with the electronic structure calculations previously reported by Hay et al., ${ }^{41}$ describing each oxyanion oxygen atom could be involved in a maximum of three hydrogen bonds. The space fill representation of complex 1 also elucidates the full engulfment of tetrahedral oxyanion sulphate inside the dimeric capsular cages of adamantane based rigid tripodal receptor $\mathbf{L}$ (Figure 1c). Figure 1d describes the full encapsulation of divalent tetrahedral sulphate by two symmetry-independent $\mathbf{L}$ receptors, depicted in two different colors for clarity. The crystal packing along the crystallographic $c$ axis shows that sulphate is enclosed within the dimeric cavity of the receptor in 2D space (Figure S3a, Supplementary Information).

\subsection{Structure of fluoride-water complex $\left[(n-T B A)\left\{(L)(F)\left(\mathrm{H}_{2} \mathrm{O}\right)\right\}\right](\mathbf{2})$}

The fluoride-water encapsulated neutral complex 2 contains a symmetry-independent neutral receptor $\mathbf{L}$ unit, one fluoride anion and its corresponding $n$-TBA counter cation along with one symmetry-independent water molecule of crystallization. Structural elucidation reveals that each symmetry-independent neutral tripodal ligand $\mathbf{L}$ first encapsulates the smaller fluoride anion with strong hydrogen bonds to all six urea protons in unimolecular half-capsular fashion. The hexa-coordinated fluoride anion in each independent half-capsular unit further attached with a water molecule in the unit cell by $\mathrm{O}_{\mathrm{w}}-\mathrm{H} \cdots \mathrm{F}$ hydrogen-bonding interactions demonstrates the overall coordination number 


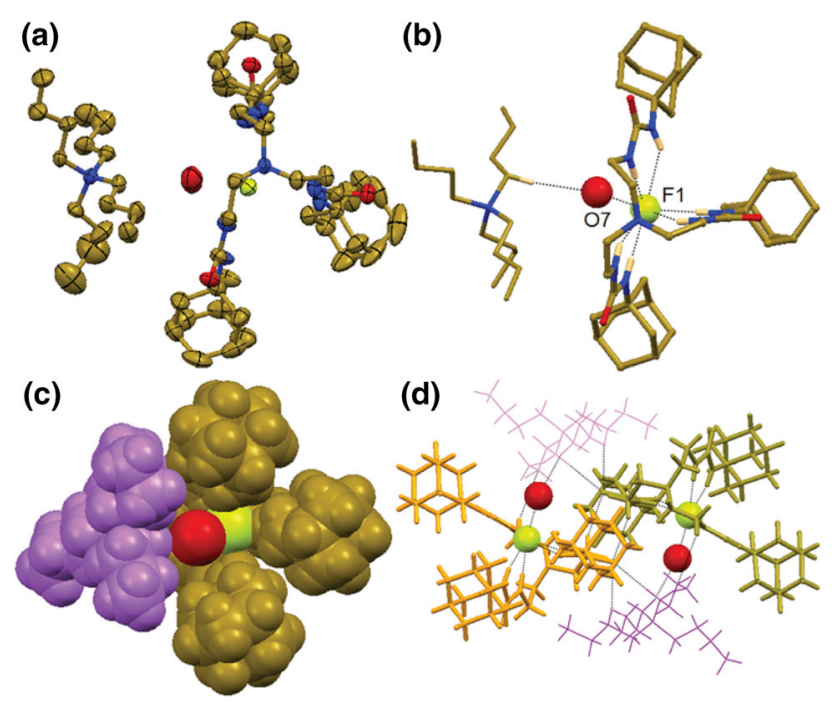

Figure 2. Partial X-ray structures of complex 2. (a) ORTEP diagram with $30 \%$ probability; (b) 1:1 unimolecular encapsulation of $\mathrm{F}^{-}$by $\mathbf{L}$ via $\mathrm{N}-\mathrm{H}_{\text {urea }} \cdots \mathrm{F}, \mathrm{O}_{\mathrm{w}}-\mathrm{H} \cdots \mathrm{F}$ and further stabilization by $n$-TBA (ball stick model) counter-cation; (c) encapsulation of fluoride-water in $n$-TBA cation-sealed environment (space filled model); (d) self-assemblies of two adjacent hydrated-fluoride entrapped cation-sealed receptor shown in different color for clarity.

of seven of smallest halide anion (Figure 2b). Note that, fluoride anion in each capsular unit is not fully engulfed within the monomeric capsule like numerous previously reported tren-based receptors, in contrary in complex $\mathbf{2}$, the open side of the unimolecular half-capsule becomes engaged in $n$-TBA cation-sealed $\left[\left(\mathrm{F}^{-}\right)\left(\mathrm{H}_{2} \mathrm{O}\right)\right]$ assembly formation, where the single water molecule acts as a bridge between the encapsulated fluoride and the tetrabutylammonium counter-cation via $\mathrm{O}_{\mathrm{w}}-\mathrm{H} \cdots \mathrm{F}$ and $\mathrm{C}_{n \text {-ТВA }}-\mathrm{H} \cdots \mathrm{O}_{\mathrm{w}}$ noncovalent interactions (Figure $2 \mathrm{~b}$ ). To the best of our knowledge, this kind of single hydrated-fluoride $\left[\left(\mathrm{F}^{-}\right)\left(\mathrm{H}_{2} \mathrm{O}\right)\right]$ anionic guest binding within the neutral receptor half-capsule is very rare in the literature. The spacefill view of complex $\mathbf{2}$ also describes the $n$-TBA cation-sealed hydrated-fluoride bound halfcapsular assemblies of adamantine-substituted neutral tripodal rigid receptor $\mathbf{L}$ (Figure 2c). Additionally, several weak $\mathrm{C}_{n \text {-ТВA }}-\mathrm{H} \cdots \mathrm{O}_{\text {receptor }}$ interactions also help to stabilize the hydrated 1:1 unimolecular host-guest half-capsule of receptor $\mathbf{L}$ (Figure 2d). The crystal packing along crystallographic $a$-axis clearly demonstrates that fluoride-water assembly is entrapped within receptor architecture and additionally stabilized by $n$-TBA counter cations (Figure S3b, Supplementary Information).

A correlation of the $\mathrm{N}-\mathrm{H} \cdots \mathrm{A}$ (Anion) angle $v s$. $\mathrm{H}$...A (Anion) distance displays that maximum number of the receptor urea $\mathrm{N}-\mathrm{H}$ hydrogen-bonding interactions with corresponding fluoride and sulphate ions in solid state are present in the strong hydrogen bonding interaction region of $d(\mathrm{H} \cdots \mathrm{A}) \leq 2.6 \AA$ and $d(\mathrm{D} \cdots \mathrm{A})$ $\leq 3.3 \AA$ and the non-covalent interactions exhibit strong hydrogen-bonding character.

\section{Conclusions}

In summary, we have designed and synthesized trenbased bulky adamantine-substituted neutral tris-urea receptor L. Larger tetrahedral sulphate anion is fully encapsulated inside the complementary cavity generated by two face-to-face oriented symmetry-independent protonated receptors (complex 1) via $\mathrm{N}-\mathrm{H}_{\text {receptor }}$. $\mathrm{O}_{\text {sulphate }}$ and $\mathrm{C}-\mathrm{H}_{\text {receptor }} \cdots \mathrm{O}_{\text {sulphate }}$ interactions as $2: 1$ host-guest capsule. On the other hand, smaller spherical fluoride anion is encapsulated as a fluoride-water cluster (complex 2) within its neutral monomeric capsular cavity and further assisted by an $n$-TBA counter cation. Counter cation-sealed fluoride-water encapsulated complex 2 shows that fluoride-water cluster is fully encapsulated within the tripodal cleft governed by six strong $\mathrm{N}-\mathrm{H}_{\text {receptor }} \cdots \mathrm{F}$, one $\mathrm{O}_{\mathrm{w}}-\mathrm{H} \cdots \mathrm{F}$ and one $\mathrm{C}_{n-\mathrm{TBA}}-\mathrm{H} \cdots \mathrm{O}_{\mathrm{w}}$ covalent interactions as 1:1 $\mathbf{L}$-fluoridewater capsule. Note that, bulky adamantane group is playing a crucial role in anion recognition not only through $\mathrm{C}-\mathrm{H} \cdots$ anion interaction but also by providing a rigid environment around anion or anion-water cluster which indirectly influences anions to bind strongly with urea $\mathrm{N}-\mathrm{H}$ bonds. Thus, receptor $\mathbf{L}$ is an excellent case to understand anion- and anion-water cluster recognition chemistry provided by $\mathrm{N}-\mathrm{H} \cdots$ anion and $\mathrm{C}-\mathrm{H} \cdots$ anion non-covalent bonds.

\section{Supplementary Information (SI)}

NMR spectra, IR spectra, H-bonding table and ESI-Mass spectra of $\mathbf{L}$ are given. Supplementary Information is available at www.ias.ac.in/chemsci.

\section{Acknowledgements}

This work was supported by CSIR and SERB (grants 01/2727/13/EMR-II and SR/S1/OC-62/2011), New Delhi, India. G.D acknowledges the CIF, IIT Guwahati and DSTFIST for providing instrument facilities. S.K. and U.M. thank IIT Guwahati for fellowships.

\section{References}

1. Bianchi A, Garcia-Espana E and James K B 1997 Supramolecular Chemistry of Anions (New York: Wiley$\mathrm{VCH})$

2. Manez R M and Sancenon F 2003 Fluorogenic and chromogenic chemosensors and reagent for anions Chem. Rev. 1034419 
3. Beer P D and Gale P A 2001 Anion recognition and sensing: The state of the art and future perspectives Angew. Chem., Int. Ed. 40486

4. Gale P A 2003 Anion and ion-pair receptor chemistry: highlights from 2000 and 2001 Coord. Chem. Rev. 240 191

5. Gale P A 2006 Structural and molecular recognition studies with acyclic anion receptors Acc. Chem. Res. 39465

6. Jose D A, Kumar D K, Ganguly B and Das A 2004 Efficient and simple colorimetric fluoride ion sensor based on receptors having urea and thiourea binding sites $O r g$. Lett. 63445

7. (a)Gale P A, Garcia-Garrido S E and Garric J 2008 Anion receptors based on organic frameworks: highlights from 2005 and 2006 Chem. Soc. Rev. 37 151; (b) Sessler J L, Gale P A and Cho W-S 2006 Anion Receptor Chemistry (Monographs in Supramolecular Chemistry) J F Stoddart (Ed.) (Cambridge UK: Royal Society of Chemistry)

8. (a) Benjamin I 2010 Structure and dynamics of hydrated ion pairs in a hydrophobic environment J. Phys. Chem. $B 114$ 13358; (b) Schatteburg G N and Bondybey V E 2000 FT-ICR studies of solvation effects in ionic water cluster reactions Chem. Rev. 100 4059; (c) Eggimann B L and Siepmann J I 2008 Size effects on the solvation of anions at the aqueous liquid-vapor interface $J$. Phys. Chem. C 112210

9. (a) Cametti M and Rissanen K 2009 Recognition and sensing of fluoride anion Chem. Commun. 2809; (b) Hossain M A, Llinares J M, Mason S, Morehouse P, Powell D and James K B 2002 Parallels in cation and anion coordination: A new class of cascade complexes Angew. Chem. Int. Ed. 114 2441; (c) Wang Q-Q, Day V W and James K B 2012 Supramolecular encapsulation of tetrahedrally hydrated guests in tetrahedron host Angew. Chem., Int. Ed. 124 2161; (d) Lakshminarayanan P S, Suresh E and Ghosh P 2006 A hybrid water-chloride structure with discrete undecameric water moieties self-assembled in a heptaprotonated octaamino cryptand Angew. Chem. Int. Ed. 453807

10. (a) Kang S O, Begum R A and James K B 2006 Amidebased ligands for anion coordination Angew. Chem. Int. Ed. 45 7882; (b) Kang S O, Hossain M A and James K B 2006 Influence of dimensionality and charge on anion binding in amide-based macrocyclic receptors Coord. Chem. Rev. 2503038

11. (a) Li A F, Wang J H, Wang F and Jiang Y B 2010 Anion complexation and sensing using modified urea and thiourea-based receptors Chem. Soc. Rev. 39 3729; (b) Amendola V, Fabbrizzi L and Mosca L 2010 Anion recognition by hydrogen bonding: urea-based receptors Chem. Soc. Rev. 39 3889; (c) Olivari M, Montis R, Berry S N, Karagiannidis L E, Coles S J, Horton P N, Mapp L K, Gale P A and Caltagirone C 2016 Tris-ureas as transmembrane anion transporters Dalton Trans. 45 11892; (d) Makela T and Rissanen K 2016 Ion pair complexes and anion binding in the solution of a ditopic receptor Dalton Trans. 45 6481; (e) Cholewiak A, Tycz A and Jurczak J 2017 8-Propyldithieno[3, 2-b : $\left.2^{\prime}, 3^{\prime}-e\right]$ pyridine-3,5-diamine (DITIPIRAM) derivatives as neutral receptors tailored for binding of carboxylates Org. Lett. 193001 ; (f) Rubio O H, Mazo S D, Monleon L M, Simon L, Temprano A G and Moran J R 2017 A cleft type receptor which combines an oxyanion hole with electrostatic interactions Org. Biomol. Chem. 15 4571; (g) Gale P A, Davis J T and Quesada R 2017 Anion transport and supramolecular medicinal chemistry Chem. Soc. Rev. 462497

12. (a) Yoo J, Kim M-S, Hong S-J, Sessler J L and Lee C-H 2009 Selective sensing of anions with calix[4]pyrroles strapped with chromogenic dipyrrolylquinoxalines $J$. Org. Chem. 74 1065; (b) Sessler J L, Cai J, Gong H Y, Yang X, Arambula J F and Hay B P 2010 A pyrrolyl-based triazolophane: a macrocyclic receptor with $\mathrm{CH}$ and $\mathrm{NH}$ donor groups that exhibits a preference for pyrophosphate anions J. Am. Chem. Soc. 132 14058

13. (a) Gale P A 2008 Synthetic indole, carbazole, biindole and indolocarbazole-based receptors: applications in anion complexation and sensing Chem. Commun. 4525; (b) Sessler J L, Cho D G and Lynch V 2006 Diindolylquinoxalines: effective indole-based receptors for phosphate anion J. Am. Chem. Soc. 128 16518; (c) Gale P A, Hiscock J R, Jie C Z, Hursthouse M B and Light M E 2010 Acyclic indole and carbazole-based sulfate receptors Chem. Sci. 1215

14. Arunachalam M and Ghosh P 2011 Anion induced capsular self-assemblies Chem. Commun. 478477

15. (a) Rudzevich Y, Rudzevich V, Schollmeyer D, Thondorf I and Bohmer V 2005 Hydrogen bonded dimers of triurea derivatives of triphenylmethanes Org. Lett. 7 613; (b) Bray D J, Antonioli B, Clegg J K, Gloe K, Gloe K, Jolliffe K A, Lindoy L F, Wei G and Wenzel M 2008 Assembly of a trinuclear metallo-capsule from a tripodal tris( $\beta$-diketone) derivative and copper(II) Dalton Trans. 1683; (c) Alajarin M, Lazaro A L, Pastor A, Prince P D, Steed J W and Arakawa R 2001 Dimerization of tris $(o-$ ureidobenzyl)amines: a novel class of aggregates Chem. Commun. 169; (d) Alajarin M, Pastor A, Orenes R-A and Steed J W 2002 Dimeric self-assembling capsules derived from the highly flexible tribenzylamine skeleton J. Org. Chem. 67 7091; (e) Alajarin M, Pastor A, Orenes R-A, Steed J W and Arakawa R 2004 Self-assembly of tris(2-ureidobenzyl)amines: A new type of capped, capsule-like dimeric aggregates derived from a highly flexible skeleton Chem.-Eur. J. 10 1383; (f) Alajarin M, Pastor A, Orenes R-A, Viviente E M, Ruegger H and Pregosin P S 2007 Structure, stability and guest affinity of tris(3-ureidobenzyl)amine capsules in Solution Chem. Eur. J. 13 1559; (g) Alajarin M, Pastor A, Orenes R-A, Viviente E M and Pregosin P S 2006 Pulsed gradient spin echo (PGSE) diffusion measurements as a tool for the elucidation of a new type of hydrogen-bonded bicapsular aggregate Chem.-Eur. J. 12 877; (h) Alajarin M, Pastor A, Orenes R-A, Goeta A E and Steed J W 2008 Highly diastereoselective self-assembly of chiral tris $(m-$ ureidobenzyl)amino capsules Chem. Commun. 3992; (i) Rudzevich Y, Rudzevich V, Schollmeyer D, Thondorf I and Bohmer V 2006 Hydrogen bonding in dimers of tritolyl and tritosylurea derivatives of triphenylmethanes Org. Biomol. Chem. 4 3938; (j) Bray D J, Liao L L, Antonioli B, Gloe K, Lindoy L F, McMurtrie J C, Wei G and Zhang X-Y 2005 Assembly of a tri-silver metallo-capsule incorporating a tripodal tris-pyridyl ligand Dalton Trans. 2082 
16. (a) Barth M C and Church A T 1999 Regional and global distributions and lifetimes of sulfate aerosols from Mexico City and southeast China J. Geophys. Res. 10430231 ; (b) Heizer W D, Sandler R S, Seal E Jr, Murray S C, Busby M G, Schliebe B G and Pusek S N 1997 Intestinal effects of sulfate in drinking water on normal human subjects Dig. Dis. Sci. 421055

17. (a) Sessler J L, Katayev E, Pantos G D and Ustynyuk Y A 2004 Synthesis and study of a new diamidodipyrromethane macrocycle. An anion receptor with a high sulfate-to-nitrate binding selectivity Chem. Commun. 1276; (b) Eller L R, Stepien M, Fowler C J, Lee J T, Sessler J L and Moyer B A 2007 Octamethyloctaundecylcyclo[8]pyrrole: a promising sulfate anion extractant J. Am. Chem. Soc. 12911020

18. Cametti M and Rissanen K 2009 Recognition and sensing of fluoride anion Chem. Commun. 2809

19. Ravikumar I, Lakshminarayanan P S, Arunachalam M, Suresh E and Ghosh P 2009 Anion complexation of a pentafluorophenyl-substituted tripodal urea receptor in solution and the solid state: selectivity toward phosphate Dalton Trans. 4160

20. Mascal M, Yakovlev I, Nikitin E B and Fettinger J C 2007 Fluoride-selective host based on anion- $\pi$ interactions, ion pairing, and hydrogen bonding: synthesis and fluoride-ion sandwich complex Angew. Chem., Int. Ed. 468782

21. Kang S O, Velde D V, Powell D and James K B 2004 Fluoride-faciliated deuterium exchange from DMSO-d 6 to polyamide-based cryptands J. Am. Chem. Soc. 126 12272

22. Dey S K, Chutia R and Das G 2012 Oxyanionencapsulated caged supramolecular frameworks of a Tris(urea) receptor: Evidence of hydroxide- and fluorideion-induced fixation of atmospheric $\mathrm{CO}_{2}$ as a trapped $\mathrm{CO}_{3}{ }^{2-}$ anion Inorg. Chem. 511727

23. Manna U, Chutia R and Das G 2016 Entrapment of cyclic fluoride-water and sulfate-water-sulfate cluster within the self-assembled structure of linear metaphenylenediamine based bis-urea receptors: Positional isomeric effect Cryst. Growth Des. 162893

24. Manna U, Nayak B and Das G 2016 Dual guest [(chloride) $)_{3}$-DMSO] encapsulated cation-sealed neutral trimeric capsular assembly: Meta-substituent directed halide and oxyanion binding discrepancy of isomeric neutral disubstituted bis-urea receptors Cryst. Growth Des. 167163

25. Dey S K and Das G 2011 Encapsulation of trivalent phosphate anion within a rigidified $\pi$-stacked dimeric capsular assembly of tripodal receptor Dalton Trans. 40 12048

26. Manna U, Nayak B, Hoque M N and Das G 2016 Influence of the cavity dimension on encapsulation of halides within the capsular assembly and side-cleft recognition of a sulfate-water cluster assisted by polyammonium tripodal receptors CrystEngComm 185036
27. Samanta S, Manna U, Ray T and Das G 2015 An aggregation-induced emission (AIE) active probe for multiple targets: a fluorescent sensor for $\mathrm{Zn}^{2+}$ and $\mathrm{Al}^{3+}$ $\&$ a colorimetric sensor for $\mathrm{Cu}^{2+}$ and $\mathrm{F}^{-}$Dalton Trans. 4418902

28. Hoque M N, Manna U and Das G 2016 Encapsulation of fluoride and hydrogen sulfate dimer by polyammoniumfunctionalised first- and second-generation tripodal: cavity-induced anion encapsulation Supramol. Chem. 28 284

29. Chutia R and Das G 2014 Hydrogen and halogen bonding in a concerted act of anion recognition: $\mathrm{F}^{-}$ induced atmospheric $\mathrm{CO}_{2}$ uptake by an iodophenyl functionalized simple urea receptor Dalton Trans. $\mathbf{4 3}$ 15628

30. Dey S K and Das G 2012 Selective inclusion of $\mathrm{PO}_{4}^{3-}$ within persistent dimeric capsules of a tris(thiourea) receptor and evidence of cation/solvent sealed unimolecular capsules Dalton Trans. 418960

31. Basu A and Das G 2013 Encapsulation of a discrete cyclic halide water tetramer $\left[\mathrm{X}_{2}\left(\mathrm{H}_{2} \mathrm{O}\right)_{2}\right]^{2-}, \mathrm{X}=$ $\mathrm{Cl}^{-} / \mathrm{Br}^{-}$within a dimeric capsular assembly of a tripodal amide receptor Chem. Commun. 493997

32. Hoque M N and Das G 2014 Cationic tripodal receptor assisted formation of anion and anion-water clusters: Structural interpretation of dihydrogen phosphate cluster and sulfate-water tetramer $\left[\left(\mathrm{SO}_{4}\right)_{2}-\left(\mathrm{H}_{2} \mathrm{O}\right)_{2}\right]^{4-}$ Cryst. Growth Des. 142962

33. Basu A and Das G 2014 A $C_{3 v}$-symmetric tripodal urea receptor for anions and ion pairs: formation of dimeric capsular assemblies of the receptor during anion and ion pair coordination J. Org. Chem. 792647

34. Hoque M N, Basu A and Das G 2012 Cyclic Pentameric Puckered Hybrid Chloride-Water Cluster $\left[\mathrm{Cl}_{3}\left(\mathrm{H}_{2} \mathrm{O}\right)_{4}\right]^{3-}$ in the Hydrophobic Architecture Cryst. Growth Des. 122153

35. Hoque M N, Basu A and Das G 2014 Pyridine-ureabased anion receptor: Formation of cyclic sulfate-water hexamer and dihydrogen phosphate-water trimer in hydrophobic environment Cryst. Growth Des. 146

36. Sheldrick G M 1995 SAINT and XPREP 5.1 edn. (Madison, WI: Siemens Industrial Automation Inc.)

37. SADABS 1997 Empirical Absorption Correction Program (Göttingen, Germany: University of Göttingen)

38. Sheldrick G M SHELXTL Reference Manual: Version 5.1 1997 (Madison, WI: Bruker AXS)

39. Sheldrick G M 2015 Crystal structure refinement with SHELXL Acta Crystallogr., Sect. C: Struct. Chem. 713

40. Mercury 2.3 Supplied with Cambridge Structural Database 2011-2012 (Cambridge, U.K.: CCDC)

41. Hay B P, Firman T K and Moyer B A 2005 Structural design criteria for anion hosts: Strategies for achieving anion shape recognition through the complementary placement of urea donor groups J. Am. Chem. Soc. 127 1810 